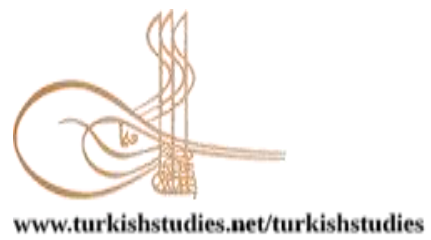

Turkish Studies

www.turkishstudies.net/turkishstudies

eISSN: $1308-2140$

BALKAN
UNIVERSITY

Sponsored by IBU

Research Article / Araștırma Makalesi

\title{
Sosyal Hizmette Teknoloji Kullanımı ve Sosyal Hizmet Uzmanlarının Dijital Yapabilirlikleri: Covid-19 Salgını Odağında Bir Değerlendirme
}

\author{
Use of Technology in Social Work and Digital Capabilities of Social Workers: An Evaluation in the \\ Focus of the Covid-19 Pandemic
}

\author{
Filiz Yıldırım* - Bilge Abukan** - Hatice Öztürk ${ }^{* * *}$ - Hülya Eker ${ }^{* * * *}$
}

\begin{abstract}
Today, technological developments, access to these developments and technology using are an important necessity for a fair and sustainable life based on human development. The use of digital technologies in social work practices is gradually becoming widespread. In social services, it is important to use information and communication technologies in in terms of collecting, classifying, storing and sharing information in addition to connecting with services according to the needs of the clients, reporting the data and in professional decision-making processes. With the Covid-19 pandemic, the effective use of technology in social services and the competence of social workers in it have become more important in order to continue the services uninterruptedly and to protect the rights of the clients. Because with this pandemic, "adaptation to the new normal" requires more active use of technology in many areas. From this point of view, the main objective of the current review study is to explain the impacts of the Covid-19 pandemic on the global and social work profession and emphasize the importance of the digital capabilities of social workers in this pandemic focus. In addition, it is aimed to highlight technology usage standards in social work practices for such a competence. This review study, showed that it is important to raise awareness of technology usage standards during the ongoing Covid-19 pandemic. Because ensuring the provision of social services by adhering to technology usage standards is necessary to protect and improve the health of both clients, social workers and society. However, technology usage standards in social work practices in our country are not yet determined. These
\end{abstract}

\footnotetext{
* Doç. Dr, Ankara Üniversitesi, Sağlık Bilimleri Fakültesi, Sosyal Hizmet Bölümü

Assoc.Prof, Ankara University, Faculty of Health Sciences, Department of Social Work

ORCID 0000-0002-6987-9485

fyildirim@ankara.edu.tr

*** Öğr. Gör. Dr., Ondokuz Mayıs Üniversitesi, Sağllk Bilimleri Fakültesi, Sosyal Hizmet Bölümü

Lecturer Dr., Ondokuz Mayis University, Faculty of Health Sciences, Department of Social Work

ORCID 0000-0002-6690-9351

bilge.abukan@omu.edu.tr

${ }^{* * *}$ Ar. Gör., Aksaray Üniversitesi, Sağlık Bilimleri Fakültesi, Sosyal Hizmet Bölümü

Res.Assist., Aksaray University, Faculty of Health Sciences, Department of Social Work

ORCID 0000-0002-4982-3257

htcoztrk@outlook.com.tr

***** Doktora Öğrencisi, Hacettepe Üniversitesi, Edebiyat Fakültesi, Sosyoloji Bölümü

Ph.D student, Hacettepe University, Faculty of Letter, Department of Sociology

ORCID 0000-0001-5899-5520
}

hulya.eker@hacettepe.edu.tr

Cite as/ Atıf: Yıldırım, F., Abukan, B., Öztürk, H. \& Eker H. (2020). Sosyal hizmette teknoloji kullanımı ve sosyal hizmet uzmanlarının dijital yapabilirlikleri: Covid-19 salgını odağında bir değerlendirme. Turkish Studies, 15(8), 38993916. https://dx.doi.org/10.7827/TurkishStudies.46164

Received/Geliș: 05 September/Eylül 2020

Accepted/Kabul: 20 December/Aralık 2020

Checked by plagiarism software

Copyright $($ C) MDE, Turkey

Published/Yayın: 25 December/Aralık 2020

CC BY-NC 4.0 
standards are important in terms of protecting the benefit of the client and preventing ethical violations with the use of technology in social services.

Structured Abstract: It is important to invest in the materials and human resources needed for social work practices to be carried out in a digital environment without interruption during Covid-19 pandemic. Because in many countries, the measures taken with this pandemic and "adaptation to the new normal" require more active use of technology, especially in the provision of social services, as in many other areas. Thus, the effective use of technology in social work and the competence of social workers in this field have become more important with this pandemic, especially in order to protect the rights of the clients and to continue the services uninterruptedly. For this reason, in the current review study, the global effects of the Covid-19 pandemic are explained and their reflections on social services are examined. In addition, in the focus of this pandemic, it is aimed to emphasize the importance of digital capabilities of social workers and to highlight technology usage standards in social work practices for such a competence.

It is important for social workers to be able to use many digital technologies such as electronic systems, applications for professionals and service users, websites, assistive robotic technologies, social media and sharing networks in their professional works. In addition, the ability of social workers to use digital technologies in issues such as reporting available data in social welfare institutions, developing and monitoring services, online and technology-supported learning, and care is seen as an important measure of competence to keep up with the times. This competence greatly facilitates the services offered to the clients and also ensures the functional management of existing services (Kennedy \& Yaldren, 2017; BASW \& SCIE, 2019). In this context, the ability of social workers to understand, comprehend and use information in the digital environment serves them to be digital literate (Gilster, 1997). Such competence supports the abilities of social workers as digital capabilities, consisting of skills, behaviors and attitudes.

Today's practices, in which social workers make more use of technology to serve their clients, to communicate with them, to collect information about them, and to train future social workers and practitioners, have brought some ethical challenges (Reamer, 2018). These difficulties made it necessary to develop new ethical standards in social work. As a matter of fact, standards have been established by important international professional organizations in social work (NASW et al., 2017; NLASW, 2012) for social workers to use technology in their professional work and practices in the digital environment. These standards are intended to guide social workers for the use of technology and increase their awareness of their ethical responsibilities when using technology. It is also important to inform social workers, employers and the community about these professional practice standards. These standards are described under four main headings: "provision of information to the public", "designing and delivering services", "gathering, managing and storing information about social services", "social work education and supervision" (NASW et al., 2017).

Newfoundland and Labrador Association of Social Services (NLASW, 2012) emphasizes that technology has become an integral part of social work practice in the "digital age". In these standards set by NLASW (2012), it is emphasized that the use of technology should be based on the values, ethical rules and principles of the social work profession. In addition, it is stated that the use of technology within competencies is important, the informed consent of the client regarding the use of technology is essential and the use of technology must comply with corporate policies, ethical standards and administration instructions. It is also stated that attention should be paid to the fact that use of technology in the professional intervention process should not exceed the limits of the jurisdiction, ensure ethical reliability in the use of technology to collect information or conduct research, as well as the issues related to conflicts of interest, bilateral and multiple relationships and boundaries.

As a result, it is important to improve the digital capabilities of social workers on the basis of knowledge, skills and value in delivering the social services. Because it is experienced that professional practices will not be possible to be conducted face to face in situations such as the Covid-19 pandemic, where professional practices are of primary importance such as health protection. In addition, it is known that social service needs of disadvantaged groups increase and new client groups emerge in crisis situations. This situation increases the need for alternative ways of producing services that will replace traditional methods. At this point, it is necessary to develop new social service practice methods with digital technologies, to support professional practices through these technologies, to determine technology usage standards in these practices and to make these standards established. Moreover, there is a need for organizational studies such as the shortcomings of digital equipment that social workers need in order to provide fast, effective and uninterrupted service in the 
event of a health crisis such as Covid-19, which services are priority for which disadvantaged groups, and at what stages of social service interventions the technology will be used.

On the other hand, it is necessary to determine the needs of social workers for their digital capabilities. In addition, there is a need for informative and awareness-raising training activities aimed at strengthening the knowledge, skill and value base in line with the needs of professional experts for a digital transformation in the provision of social services. At this point, getting support from social work academics and providing evidence-based information is valuable. What is more, the studies of social service academics on new methods and alternative professional practices that can be used effectively through digital technologies in crisis situations such as the Covid-19 pandemic may also be useful in this regard. In addition, it is realized that the ability of social service practitioners to use technology in crisis situations is important today. For this reason, in social work programs; it is necessary to question the competencies to provide digital competence to the social workers of the future.

Keywords: Social work, Technology use, Digital capability, Covid-19 pandemic, Standard.

Öz: Günümüzde teknolojik gelişmeler, bu gelişmelere erişim olanakları ve teknoloji kullanımı insani gelişim temelinde adil ve sürdürülebilir yaşam için önemli bir gerekliliktir. Sosyal hizmet uygulamalarında da dijital teknolojilerin kullanımı giderek yaygınlaşmaktadır. Sosyal hizmetlerde gerek bilginin toplanması, sınıflandırılması, saklanması ve paylaşılması konusunda gerekse müracaatçıların gereksinimlerine göre hizmetlerle bağlantı kurulması, verilerin raporlaştırılması ve mesleki karar alma süreçlerinde bilgi ve iletişim teknolojilerinin kullanımı önemlidir. Müracaatçıların haklarının korunması ve hizmetlerin kesintisiz devam edebilmesi için sosyal hizmetlerde teknolojinin etkin kullanımı ve sosyal hizmet uzmanlarının bu konudaki yetkinlikleri Covid-19 salgınıyla birlikte daha da önemli hale gelmiştir. Çünkü bu salgınla birlikte "yeni normale uyum" birçok alanda teknolojinin daha aktif kullanımını gerektirmektedir. Buradan hareketle mevcut derleme çalışmanın temel amacı Covid-19 salgınının küresel etkilerini ve sosyal hizmet mesleğine olan etkilerini belirterek bu salgın odağında sosyal hizmet uzmanlarının dijital yapabilirliklerinin önemini açıklamak ve vurgulamaktır. Bu derleme çalışma, Covid-19 salgını sürecinde teknoloji kullanım standartlarına farkındalık kazandırmanın önemli olduğunu göstermiştir. Çünkü teknoloji kullanım standartlarına bağlı kalarak sosyal hizmetlerin sunumunu sağlamak hem müracaatçıların hem sosyal hizmet uzmanlarının hem de toplumun sağlığını korumak ve iyileştirmek için gereklidir. Ancak ülkemizde sosyal hizmet uygulamalarında teknoloji kullanım standartları henüz belirlenmiş değildir. Bu standartlar müracaatçının yararının korunması ve sosyal hizmetlerde teknoloji kullanımı ile birlikte etik ihlallerin ortaya çıkmaması açısından önemlidir.

Anahtar Kelimeler: Sosyal hizmet, Teknoloji kullanımı, Dijital yapabilirlik, Covid-19 salgını, Standart.

\section{Giriş}

İnsani hizmet örgütlerinde önemli bir mesleki alan olarak sosyal hizmette "bireylerin, ailelerin, grupların ve toplulukların bireysel ve toplumsal iyilik hallerinin sağlanması" önemli bir hedeftir (CASW, 2008). Sosyal hizmet; birey ve çevresi içindeki etkileşime odaklanarak birey, aile, grup ve toplumların iyilik halinin artırılması için sosyal değişim, insan ilişkilerinde sorun çözme, güçlendirme ve özgürleştirmeyi temel alır (IFSW, 2000). İyilik hali; "bireysel, aile, topluluk ve toplum düzeyi" olmak üzere 4 temel boyuttan oluşur. Bu kavramsallaştırmada iyilik hali; refah durumunu çok boyutlu ele alarak çevre, coğrafi özellikler, sosyo-ekonomik ve politik güçleri de içermektedir (La Placa, McNaught ve Knight, 2013; Attepe-Özden vd., 2017). İyilik halinin bireysel boyutunda; bireyin kişisel iyi oluşu hem öznel deneyimlerin hem de yapısal koşulların etkisi ele alınarak incelenmektedir. Aile boyutu ise aile sağlığ kişilerarası ve kuşaklararası ilişkilerin kalitesi, ailenin ekonomik ve diğer kaynaklara erişimi ile aile üyelerinin bu konudaki olumlu ve olumsuz değerlendirmelerini kapsar. İyilik halinin topluluk boyutu; birey, aile ve toplum düzeyinde sosyal, kültürel ve psikolojik ihtiyaçları ifade eder. Toplumsal boyutta iyilik hali ise refah ve insani gelişme temelinde, bireysel ve toplumsal katılımı esas alır ve toplumsal eşitsizliklere odaklanır (Attepe-Özden vd., 2017). Bu noktada insani 
gelişmedeki eşitsizlikler toplumsal uyum, ekonomi, yönetim ve kurumlara güven gibi birçok alana etki ederek toplumun iyilik halini doğrudan etkiler (UNDP, 2019).

Günümüzde mevcut eşitsizliklerin yanı sıra teknolojik gelişmeler ve bu gelişmelere erişim olanakları, insani gelişim temelinde adil ve sürdürülebilir bir yaşam için önemli bir belirleyici haline gelmiştir. Nitekim sosyal hizmet alanında hem planlı müdahale süreci aşamalarında (tanışma bağlantı kurma, ön değerlendirme, planlama, uygulama, son değerlendirme, sonlandırma ve izleme) hem de sosyal hizmet uzmanlarının mesleki çalışmalarının pek çok düzeyinde (sosyal politika, örgüt, uzman ve müracaatçılar için) dijital teknolojilerin kullanımı giderek yaygınlaşmaktadır. İnsani hizmetlerin önemli bir parçası olarak gerek bilginin toplanması, sınıflandırılması, saklanması ve paylaşılması konusunda gerekse müracaatçıların gereksinimlerine göre hizmetlerle bağlantı kurulması, verilerin raporlaştırılması, mesleki karar alma süreçleri gibi pek çok aşamada bilgi ve iletişim teknolojileri önem kazanmaktadır (Öngen, 2014). İlk olarak 1982 yılında çevrimiçi kendine yardım destek grupları biçiminde ortaya çıkan hizmetler, 1990'lı yıllara doğru ücretli çevrimiçi danışmanlık hizmetleri ve e-terapi uygulamaları ile ruh sağlığı hizmetlerinin çevrimiçi ortamda sunulmasına ortam hazırlamıştır (Reamer, 2019). Bilgi ve iletişim teknolojilerinin gelişimiyle birey ve toplum refahını temel alan sosyal hizmet uygulamaları bu sayede çevrimiçi ortamda daha görünür hale gelmeye başlamıştır. İleri teknolojiler sayesinde bilgiye erişimin daha hızlı hale gelmesi, kayıt ve değerlendirmenin daha kolay yapılabilmesine imkân sağlamış; çevrimiçi grup çalışmaları, edanışmanlık ve e-terapi uygulamaları sosyal hizmet alanına büyük oranda katkıyı beraberinde getirmiştir (Csiernik vd., 2006; Midkiff ve Joseph Wyatt, 2008; Hanley, 2009).

Giderek gelişen ve kullanım alanı yaygınlaşan dijital teknolojiler, birçok mesleğin uygulama alanında kendine yer bulmaktadır. Bu bağlamda her mesleğin, dijital teknolojileri mesleki uygulamalarına entegre etme gereksinimi ortaya çıkmaktadır. Birey, aile, grup ve toplum refahını yükseltmeyi hedefleyen sosyal hizmet uygulamalarında da dijital teknolojilerin etkin kullanımı yeni olmamakla birlikte giderek önem kazanmaktadır (Tuncay, 2010). Çünkü çağın gereklerine uyum sağlayabilme ve teknolojik gelişmelerin sunduğu olanakları müracaatçı lehine kullanabilme ile yenilikçi yaklaşımları takip etme, mesleki beceri ve yetkinlik ölçüsü haline gelmiştir (Birinci, 2018). Bu bağlamda sosyal hizmet mesleki yeterliliklerinin ve hizmet sunma biçimlerinin de bilgi ve iletişim teknolojileri ile uyumlu hale getirilmesi önemlidir. Bunun yanı sıra teknolojik dönüşüm; bilgiye erişimi hızlandırmakta, kayıt ve değerlendirme süreçlerini de değiştirmektedir (Csiernik vd., 2006; Taylor, 2017). Dünya genelinde pek çok ülkede Covid-19 salgınıyla bu gerçeklik daha derinden hissedilmiştir. $\mathrm{Bu}$ salgınla birlikte alınan tedbirler ve "yeni normale uyum" birçok alanda teknolojinin daha aktif kullanımını gerekli kılmıştır. Şüphesiz dezavantajlı grupların iyilik halinin sağlanması odağında profesyonel müdahaleler gerçekleştiren sosyal hizmet mesleği de bu süreçten payını almıştır. Böylece müracaatçıların haklarının korunması ve hizmetlerin kesintisiz devam edebilmesi odağında sosyal hizmette teknolojinin etkin kullanımı ve sosyal hizmet uzmanlarının bu konudaki yetkinlikleri bu süreçle birlikte önemli bir gereklilik haline gelmiştir. Bu nedenle mevcut derleme çalışmada öncelikle Covid-19 salgının küresel etkileri açıklanarak sosyal hizmet mesleğine yansımaları açıklanmaktadır. Ayrıca bu salgın odağında sosyal hizmet uzmanlarının dijital yapabilirliklerinin önemini vurgulamak ve böyle bir yetkinlik için sosyal hizmet uygulamalarında teknoloji kullanım standartlarını öne çıkarmak da amaçlanmaktadır.

\section{Covid-19 Salgınının Küresel Etkileri}

Covid-19, dünya üzerinde farklı coğrafyalarda hızla yayılarak salgına neden olmuş ve küresel bir kriz haline gelmiştir. Küresel bir sağlık krizi olarak Covid-19 salgını; hemen her ülkede sosyal, ekonomik ve siyasi dengeleri değiştirmiştir (UN, 2020a). Dünya Sağlık Örgütü’nün Covid19 Durum Raporu'nda (WHO, 2020a) Türkiye'yi de içerecek biçimde tedbir önerileri sunulmuştur. Birçok ülke, karantina ve bireylerin hareketlerinin kısıtlanması dâhil, Covid-19'un bulaşma riskini azaltmak ve etkisini en aza indirmek amaciyla toplumun hemen hemen her kesimini ilgilendiren 
önlemler almıştır. Bunlar arasında kişisel koruyucu önlemlerden, fiziksel mesafe ve çevresel önlemlere kadar pek çok tedbire yer verilmiştir. Fiziksel mesafe önlemleri; bireyler (örneğin vakaların izolasyonu ve karantina uygulaması) ya da topluluklar bağlamında nüfusun belirli ya da büyük kesimi için geçerlidir. Dolayısıyla bireysel ya da topluluklara yönelik önlemlerin birbirlerini tamamlaması hedeflenmiştir (WHO, 2020b).

Dünya çapındaki bu önemli salgın, çok sayıda insanın hastalanmasına ve yaşamını yitirmesine neden olmaya devam etmektedir. Küreselleşmenin bir sonucu olarak insanların yaşam biçiminin değişmesi ve insanlar arasındaki etkileşimin artması; bilgi ve deneyimlerin paylaşılmasını kolaylaştırırken, hastalıkların yayılmasını hızlandırmaktadır (Akın ve Gözel, 2020, s.515). Bu nedenle salgın hastalıklar, küresel olarak birbiriyle uyumlu eylemleri gerektirmektedir. Çünkü bu hastalıklar; sosyal, ekonomik, sağlık ve siyasi açıdan ciddi sonuçlara neden olan yıkıcı olaylardır (ILO, 2020; UN, 2020a; WHO, 2020c).

Birleşmiş Milletler (UN, 2020b) de Covid-19 salgınının, toplumları derinden ve uzun vadede farklı boyutlarda etkileyeceğini belirterek ülkeleri; koordineli, kapsamlı ve çok boyutlu müdahaleye, küresel ve toplumsal işbirliğine davet etmektedir. Tarihsel süreçte salgınların sonuçları bakımından ciddi nüfus kayıpları ile ekonomik ve sosyal alanda önemli ölçüde değişimleri ve dönüşümleri beraberinde getirdiği bilinmektedir. Nitekim Covid-19 salgınıyla ekonomi, ticaret, eğitim ve hizmet sektöründe birtakım yapısal değişimler ortaya çıkmaya devam etmektedir (TÜBA, 2020).

$\mathrm{Bu}$ salgının özellikle dünyadaki işgücü piyasası üzerinde önemli etkiler yarattığı vurgulanmaktadır. Covid-19 salgınının, çalışanların sağlı̆̆ına etkileri ve oluşturacağı ekonomik şoklar çalışma yaşamını özellikle; "iş sayısı (hem işsizlik hem de eksik istihdam)", "iş kalitesi (ücretler ve sosyal korumaya erişim)" ve "olumsuz işgücü piyasası" açısından etkileyeceği belirtilmektedir. Böylece çalışma yaşamındaki olumsuz sonuçlara karşı bazı çalışanların daha savunmasız hale geleceği vurgulanmaktadır (ILO, 2020; WHO, 2020c).

Diğer yandan toplumdaki eşitsizliği daha da kötüleştireceği düşünülen Covid-19 salgınının çalışan yoksulluğunu da arttıracağı açıktır. Örneğin serbest meslek çalışanları, kısa süreli ve geçici işçiler dâhil korumasız çalışanlar, ücretli izin ya da hastalık izni gibi haklara erişemedikleri için geleneksel sosyal koruma mekanizmaları bu çalışanları daha az korumaktadır. Böylece Covid-19 salgını nedeniyle bu çalışanların orantısız biçimde zarar görmeleri kaçınılmaz hale gelmektedir (ILO, 2020). Bu sorunları da içerecek biçimde yapılan düzenlemeler salgının kontrol altına alınmasına ve ortadan kaldırılmasına odaklanmakla birlikte Covid-19 Pandemi Değerlendirme Raporu'nda (TÜBA, 2020) da ifade edildiği gibi ekonomik ve sosyal alanda önemli değişim, dönüşüm ve gelişmeler yaşanmaya devam etmektedir.

\section{Covid-19 Salgınının Sosyal Hizmet(ler)e Etkisi}

Covid-19 salgını pek çok savunmasız grubu farklı biçimde etkilemekte, savunmasızlıklarını pekiştirmekte ve istismara maruz kalma risklerini de arttırmaktadır. Bu salgın sürecinde kayıp riski en yüksek gruplar arasında yaşlılar, kronik hastalığı olanlar, bağışıklık sistemi zayıf olanlar, kalp hastalığı, solunum yolu rahatsızlığı ve şeker hastalı̆̆ olanlar sıralanmaktadır (UNFPA, 2020). Ayrıca kadınların, engellilerin, çocukların, göçmenlerin ve azınlık grupların da bu süreçte daha savunmasız hale geldiği vurgulanmaktadır. Bu salgın; kayıt dışı ekonomiye daha çok bağımlı olma, sosyal hizmetlere ve siyasi güce daha az erişim, sorunlarla yetersiz başa çıkma ve uyum kapasitelerinin ve firsatlarının az olması, teknolojiye erişimlerinin daha sınırlı olması gibi nedenlerle bu grupların toplumda diğer gruplara göre daha dezavantajlı olmalarına neden olmaktadır (IASC, 2020). Örneğin savunmasız bir grup olarak çocuklar Covid-19 salgını hakkında kamuya açık bilgilere erişimde, bu bilgileri algilamada ve gerekli dikkati göstermede yetersizdirler. Genellikle korku ve endişelerini ifade edemedikleri için bu salgın karşısında savunmasızlıkları artmaktadır. Diğer yandan ebeveynlerin iş için dışarı çıkması ve okulların kapalı olması nedeniyle çocukların uzun süre evde kalmaları, güvenlik ve emniyet sorunlarını da beraberinde getirmektedir. Ayrıca ebeveynlerin 
kaygıları ve umutsuzlukları evde çocuklarına şiddet uygulamalarına neden olabilmektedir (IASC, 2020). Bu dönemde örneğin kadın ve kız çocukları hane içinde gerilimin artması nedeniyle eş/partner şiddeti başta olmak üzere aile içi şiddet türlerine, cinsel sömürüye ve istismara daha fazla maruz kalabilmektedirler. Örneğin 2013-2016 yıllarında Ebola salgınının Batı Afrika'daki ekonomik etkileri kadınların ve çocukların daha fazla cinsel şiddete maruz kalmalarına neden olmuştur (UNFPA, 2020).

Covid-19 salgını sürecinde gerekli uyarılar ve alınacak tedbirler noktasında dezavantajlı gruplar arasında sıralanan engelli bireylerin iletişim ihtiyaçları onlar için oldukça sınırlıdır. Genellikle karar verme alanlarından dışlanmakta ve salgın hizmetlerinden yararlanmaya yönelik bilgiye erişimde sorun yaşayabilmektedirler. Bu bireyler sosyal aktivite, istihdam ve eğitim gibi toplumda birçok alandan izole olmakta ve ihtiyaçlarını karşılamada zorlanmaktadırlar (IASC, 2020).

Özellikle karantina, izolasyon ve fiziksel-sosyal mesafe Covid-19 salgını sürecinde; çocuk, genç, yaşlı, çalışan vb. pek çok dezavantajlı bireyin psiko-sosyal iyilik halini olumsuz etkilemiştir. Karantina durumu, bireylerin haklarına ve özgürlüklerine kısitlama getirmesi nedeniyle bireylerde ruhsal, psikolojik ve davranışsal bozukluklara yol açmıştır. Yapılan bir çalışmaya (Brooks vd., 2020) göre salgın hastalıklarda, virüs bulaşmış kişi ile temas eden ve karantinaya alınan bireylerde korku, sinirlilik, üzüntü ve suçluluk duygularının açığa çıktığı belirlenmiştir. Covid-19 salgınının uzun süreli etkileri arasında kalabalıktan kaçınma, el yıkamada aşırılık gibi davranışsal değişiklikler gözlemlenmiştir. Ayrıca salgın sürecinde karantina durumunun ruhsal etkileri bakımından en fazla risk altındaki grubun, sağlık çalışanları olduğu vurgulanmaktadır. Karantinada çalışan sağlık personelinin ilerleyen zamanlarda hastalarla doğrudan teması en aza indirme davranışının, kaçınma ile ilgili olduğu belirtilmektedir (Yıldız vd., 2020).

Kriz durumları ve sonrasında birey ve ailelerde akut stres bozukluğu, majör depresyon gibi çeşitli psikolojik uyumsuzluk ve ruh sağlığı sorunları; iş ve eğitim kaybı gibi ekonomik sorunlar görülebilmekte ve bu sorunlar duygusal, fiziksel ve ekonomik nitelik taşımaktadır. Kriz sürecinde bireylerin ve toplumun mevcut gereksinimlerinin tespit edilmesi, krizle baş etme kapasitelerinin ve iyileşme becerilerinin geliştirilmesinde psikososyal destek hizmetleri önemlidir. Bu destekler kriz durumundan etkilenen bireylerin, normal yaşamlarına geçiş süreçlerini hızlandırmaya yardımcı olmaktadır (Arslan-Tomas ve Şavur, 2018; Tuncay, 2004). Kriz sonrasında, kriz sürecinden etkilenen bireylere ve ailelerine yönelik psikososyal destek için müdahale yöntemleri dört temel düzeyde ele alınmaktadır. İlk olarak temel ihtiyaçların karşılanması ve güvenliğin sağlanması ile kriz sonrasında bireylerin işlevselliklerinin artırılması hedeflenmektedir. Aile ve toplum desteğini içeren çalışmalarla psikososyal iyilik halini geliştirmek ise ikinci düzey kapsamında yer alır. Daha ileri düzeyde psikolojik desteğe ihtiyaç duyan bireylere yönelik olarak "odaklı ve uzmanlaşmamış" birey, aile ve grup müdahalesi üçüncü düzeyde gerçekleştirilmektedir. Dördüncü düzeyde ise bireylere ve ailelerine yönelik profesyonel tedaviler uygulanmaktadır (Arslan-Tomas ve Şavur, 2018). Covid-19 gibi önemli bir sağlık krizi ve biyolojik afet durumlarında mikro düzeyde birey ve aile; mezzo düzeyde kriz ve afet çalışanları ile resmi gruplar; makro düzeyde ise bütün olarak toplum üzerindeki etkilerin belirlenmesi önemlidir. Ayrıca böyle bir kriz ve afetten etkilenen grupların gereksinimlerine uygun mesleki müdahalelerin ve çalışmaların işlevsel ve sistematik bir biçimde planlanması, uygulanması ve bunun takibinin yapılması önem arz eder (Tuncay, 2004). Sosyal hizmet uzmanları Covid-19 gibi sağlık krizi ve biyolojik afet durumları öncesinde koruyucu-önleyici; sonrasında ise tedavi edici-iyileştirici ve geliştirici-destekleyici fonksiyonlar üstlenerek mikro-mezzo ve makro boyutta danışmanlık, kaynak yönetimi ve eğitim işlevlerini yerine getirirler (Buz, 2002; Duyan, 2002).

Görüldügü üzere krizler, sadece birey ve aileleri değil aynı zamanda ülkeler düzeyinde geniş toplulukları da içerecek biçimde yapısal ve kurumsal boyutlarda yıkıcı etkilere müdahaleyi gerektirebilir. İyilik halini odağına alan sosyal hizmet uzmanları, Covid-19 gibi küresel sağlık krizi 
ve biyolojik afet durumlarının birey ve toplum üzerindeki ruhsal, sosyal, kültürel ve ekonomik etkileri sonucunda ortaya çıkan toplumsal sorunların çözümü ve gerekli politikaların üretilmesi noktasında da önemli rol ve sorumluluklara sahiptir. Bu toplumsal sorunların tespit edilmesi ve çözülmesi konusunda öncülük etmesi beklenen sosyal hizmet uzmanları, içinde yaşadığımız bilgi toplumu ile uyumlu olarak bu sorunlara yönelik müdahalelerin planlanmasından uygulanmasına ve takibine kadar hizmetlerin sunumu ve politika üretilmesi noktasında da teknolojik gelişmeleri takip etmeleri gerekmektedir (Öngen, 2014).

\section{Sosyal Hizmetlerde Dijital Yapabilirliklerin Önemi}

Tuncay (2010) sosyal hizmette bilgi iletişim teknolojilerinin kullanımını dört düzeyde açılamaktadır. Bunlar (i)sosyal politika ve toplum düzeyi (sosyal politika geliştirme, bilgiyi yaygınlaştırma, kurumlararası eşgüdümü sağlama), (ii)kurum yönetimi düzeyi (bilgi toplama ve raporlaştırma, karar verme sürecini destekleme, finansal yönetimi kolaylaştırma, etkili personel ve gönüllü yönetimi), (iii)doğrudan hizmet sunumu düzeyi (profesyonellerin çalışmalarını yönetmesi ve raporlaştırması, hizmet alanlarla etkileşimin desteklenmesi), (iv)hizmet alanlar düzeyi (eğitim ve bilgilendirme, internet destek grupları) olarak ifade edilmektedir. Sosyal hizmet uzmanlarının bu teknolojileri kullanabilmeleri dijital yapabilirlikleri ile yakından ilişkilidir.

Dijital yapabilirlik kimi zaman dijital okuryazarlık kimi zaman ise medya okuryazarlığı ya da bilgi okuryazarlı̆ğ kapsamında açıklanmaktadır. Bununla birlikte genellikle online olarak bilginin oluşturulması, işlenmesi, ölçülmesi, paylaşılması ve online bilgiye erişim sağlanabilmesi için modern teknolojileri kullanma yeteneği olarak da ifade edilmektedir (Taylor, 2019).

Sosyal hizmet uzmanlarının yaşlı, engelli, kronik ruhsal hastalıkları olan pek çok dezavantajlı gruplara yönelik hizmet sundukları düşünüldüğünde, bu teknolojileri kullanabilmeleri onların dijital yapabilirlikleri ile paralellik gösterecektir. Özellikle elektronik ortamda bu hizmetleri daha önce yürütmemiş olan sosyal hizmet uzmanlarının dijital teknolojileri kullanabilmeleri için gerekli bilgi ve becerileri yetersiz düzeyde olabilir.

İngiltere'de Dunn, Braddell ve Sunderland (2014) tarafından sosyal bakım alanında çalışan ve aralarında sosyal hizmet uzmanlarının da bulunduğu yönetici ve personelden oluşan 539 kişi üzerinde dijital teknolojilerin kullanımı ve çalışanların yapabilirliklerini belirlemek üzere bir araştırma yapılmıştır. Araştırmaya göre dijital teknolojiler özellikle kurum içindeki ve dışındaki iletişim mekanizmaları, işgücü geliş̧irme ve insan yönetimi gibi genel örgütsel faaliyetlerde yaygın olarak kullanılmasına rağmen sosyal bakım sektöründeki işgücünün yaklaşık üçte birinden fazlasının temel çevrimiçi becerilere sahip olmadığı ortaya çıkmıştır. Buradan hareketle dijital yapabilirlikleri yetersiz olan sosyal hizmet uzmanlarının, dijital ortamda profesyonel hizmet sunmalarının mümkün olamayacağını söylemek mümkündür. Zira yapılan bir çalışma da mesleki uygulamaların günümüz koşullarında dijital ortamlarda sunumunun, profesyonellik gerektirdiğini vurgulamaktadır (Evans, 2008).

İngiltere'de Sosyal Hizmet Uzmanları Derneği ve üniversite (BASW ve SCIE 2019) iş birliğinde yürütülen başka araştırmalar da mevcuttur. Buna göre İngiltere'de bir üniversiteye bağlı enstitü (SCIE) ve İngiltere Sosyal Hizmet Uzmanları Derneği (BASW) tarafindan yürütülen bir araştırmada (BASW ve SCIE 2019) paydaşlarla danışma grubu toplantıları, farklı rollerdeki ve kıdemlerdeki 40'tan fazla sosyal hizmet uzmanı ve 15 sektör lideri ile görüşmeler gerçekleştirilmiştir. Bunun yanı sıra Ulusal Sağlık Sistemi'nde, yerel yönetimlerde, özel, gönüllü ve bağımsız sektörlerde, sosyal hizmet eğitiminde, çocuk ve yetişkin hizmetlerinde çalışan toplam 647 katılımcıya anket uygulanmıştır. $\mathrm{Bu}$ araştırma sonucunda sosyal hizmet uzmanlarının yarıya yakınının (\%47), dijital becerilerini "iyi” olarak değerlendirdikleri belirlenmiştir. Bu uzmanların sırasıyla değerlendirme, bakım ya da planlama; çocuk ya da yetişkinleri koruma; müracaatçılarla rutin iletişim ve hizmet sağlama ile kurumlararası bilgi paylaşımı konularında dijital teknolojileri kullandıkları ortaya çıkmıştır. Bu uzmanlara göre mevcut teknolojinin, sosyal hizmetlerin ve iş 
süreçlerinin bütünleştirilmesinde faydalı olduğu ve bu süreçte kurumlararası işbirliği ve koordinasyon açısından da bu teknolojilerin önemli olduğu ifade edilmiştir. Ayrıca uzmanlar mesleki çalışmalarında etik konulara, veri güvenliği ve sosyal medya üzerinden gelen tehditlere önem verilmesi gerektiğini, üniversite eğitiminin dijital uygulamaya hazırlamadığını, dijital teknolojiler konusunda eğitim gereksinimi olduğunu, teknoloji sağlayıcılarla sosyal hizmet uzmanlarının birlikte çalışması gerektiğini belirtmişlerdir (BASW ve SCIE, 2019).

Ülkemizdeki konuya ilişkin bazı çalışmalarda ise teknoloji kullanımının, sosyal hizmet akademisyenleri (Ege ve Altındağ, 2018) ve sosyal hizmet eğitimi (Tuncay, 2020) üzerinden incelendiği görülmektedir. Öngen (2014)'in araştırmasına göre meslek elemanlarının bilişim sistemlerini yoğun olarak kullandıkları, bu sistemleri kullanırken bilgiye erişim ve gerekli işlemleri yapma konusunda zaman zaman sorun yaşadıkları, bu teknolojilerin daha çok kuruluş yönetimi düzeyinde kullanıldığı belirlenmiştir. Ayrıca sosyal politika oluşturma, doğrudan hizmet sunma ve hizmet alanlar düzeyinde bu teknolojilerin kullanımının yetersiz kaldığı saptanmıştır (Öngen, 2014). $\mathrm{Bu}$ noktada bilişim teknolojilerinin kullanımının yaygınlaştı̆̆ı, bu konuda hizmet sağlayıcıların yetkinliklerinin önemli hale geldiği ve böylece sosyal hizmetlerde yeni uygulama yöntemlerinin geliştirilmesine ve mesleki uygulamaların desteklenmesine gereksinim olduğu söylenebilir (Tuncay, 2005).

Sosyal hizmet uzmanlarının mesleki çalışmalarında elektronik sistemler, profesyoneller ve hizmet kullanıcılarına yönelik uygulamalar, web siteleri, yardımcı robotik teknolojiler, sosyal medya ve paylaşım ağları gibi pek çok dijital teknolojileri kullanabilmeleri önemlidir. Ayrıca kurumlarında mevcut verilerin raporlanması, hizmetlerin geliştirilmesi ve takip edilmesi, çevrimiçi ve teknoloji destekli öğrenme, bakım gibi konularda sosyal hizmet uzmanlarının dijital teknolojileri kullanabiliyor olmaları çağa ayak uydurabilmeleri için önemli bir yetkinlik ölçüsü olarak görülmektedir. Bu yetkinlik, müracaatçılara sunulan hizmetlere büyük ölçüde kolaylık sağlamakta ve bu durum mevcut hizmetlerin etkin ve işlevsel bir biçimde yönetilmesini sağlamaktadır (Kennedy ve Yaldren, 2017; BASW ve SCIE, 2019). Bu bağlamda sosyal hizmet uzmanlarının dijital ortamdaki bilgiyi anlama, kavrama ve kullanma becerisi, dijital okuryazar olmalarına hizmet etmektedir (Gilster, 1997). Böyle bir yetkinlik dijital yapabilirlikler olarak sosyal hizmet uzmanlarının beceri, davranış ve tutumlarından oluşan yeteneklerini desteklemektedir. Böylece iletişim, işbirliği ve katılım; öğretme, öğrenme ve kendini geliştirme; bilgi, veri ve içerik okuryazarlığı; dijital üretkenlik, yenilik ve araştırma yapabilme; dijital teknolojileri kullanma konusunda teknik yeterlilik ve bu teknolojileri kullanırken dijital kimlik, mahremiyet ve güvenlik konularında bilinçli olma teknoloji kullanımı için gerekli yapabilirlikler olarak sıralanabilir (HEE, 2016; Kennedy ve Yaldren, 2017; NHS; 2018).

\section{Covid-19 Salgını Odağında Sosyal Hizmetlerde Dijital Yapabilirliklerin Önemi}

Özellikle Covid-19 salgını ile birlikte yüz yüze iletişim konusunda sosyal ve fiziksel mesafenin korunmasının önemi düşünüldüğünde sosyal hizmetlerin sunumunda dijital teknolojileri kullanabilme yetkinliğinin diğer bir ifadeyle "dijital yapabilirlikler"in daha önemli olacağı açıktır. Zira Covid-19 salgınında yaşamını yitirenler düşünüldüğünde ölenlerin yakınları başta olmak üzere bu hastalığa yakalanıp iyileşen ya da bu hastalık sürecinde karantinada kalan bireylerin yaşamlarını sürdürebilmeleri, bu kriz ile başa çıkabilmeleri ve günlük yaşamlarına uyum sağlayabilmeleri için çoğu bireyin sosyal hizmetlere olan gereksinimi artmaya devam etmektedir. Sosyal hizmet uzmanlarının bu salgın ile birlikte hem kendileri hem de müracaatçı gruplarını korumaları için dijital teknolojilerle uyumlu ve bu hizmetleri "müracaatçı odaklı" olacak biçimde sürdürebilmeleri önemlidir. Ayrıca Covid-19 salgınına karşı çözüm üretilse bile ülkeler, böyle bir salgın ihtimaline karşı tüm hizmet alanlarında dijital teknolojileri kullanarak bu hizmetlerin aksamadan sürdürülebilmesi için özellikle kamu politikalarında dijitalleşmeye olan yatırımlarını yeniden gözden geçirmek durumunda kalacaklardır. 
Covid-19 salgını çoğu ülkede kadın, çocuk, yaşlı, engelli, mülteci vb. pek çok bireyin temel ihtiyaçlara erişimlerinin kısıtlanmasına yol açmış ve sosyal hizmetlerin sunulmasını zorlaştırmıştır. Sosyal hizmet mesleği refahın artırılması ve eşitsizliklerin azaltılmasına yönelik mikro, mezzo ve makro düzeyde uygulamaların gerçekleştirilmesinde önemli yere sahiptir.

Salgının hızla yayılması ülkelerdeki kurum ve kuruluşlarda dijital altyapıların, toplumlarda ise teknolojik bilgi ve beceri düzeyinin gözden geçirilmesini gerektirmektedir. Nitekim Deloitte tarafından hazırlanan "Yeni Nesil Teknolojilerin COVID-19 Mücadelesindeki Önemi" adlı rapora göre ülkelerin teknolojiyi kullanma durumları salgının kontrol altına alınması ve yayılımının azaltılması bakımından önem teşkil etmektedir (Deloitte, 2020). Rapora göre Çin "yapay zekâ, büyük veri, akıllı uygulamaları (ücretsiz çevrimiçi sağlık danışmanlığı gibi)" kullanarak salgını kontrol altına almaya çalışmaktadır. Benzer şekilde Amerika Birleşik Devletleri'nde yapay zekâ tabanlı akıllı sağlık uygulamaları sayesinde sağlık hizmetleri dijital araçlar kullanılarak uzaktan tedavi planları yapılmakta ve hasta ile ailesine bilgilendirmeler yapılmaktadır (Deloitte, 2020). Salgın sürecinde yeni nesil teknolojiler, farklı gruplarla çalışan sosyal hizmet uzmanlarının dijital yapabilirliklerinin özellikle hizmetlerin sunulması ve geliştirilecek olan akıllı uygulamaların müracaatçılara uygun biçimde tasarlanması bakımından önemini gözler önüne sermektedir.

Sağlık hizmetlerinin dijital teknolojiler aracılığıyla sunulmasında öne çıkan tele-sağlık uygulamaları, özellikle salgın sürecinde bulaş riskinin en aza indirilmesi ve erken tanı-tedavi hizmetlerinin sağlanması bakımından önemlidir (Smith vd., 2020). Vietnam'da özellikle salgın ile birlikte üniversite ve hastanelerde çeşitli tele-sağlık projeleri oluşturulmuştur. Bazı hastanelerde akıllı uygulamalar tarafindan hasta bireyler görüntülü olarak incelenirken, bazı üniversite hastanelerinde de "dijital hastane" projesi gerçekleştirilmiştir. Dijital hastane projesinde doktorlararası mesleki koçluk sistemi ve hasta ile doktor arasında iletişimin sağlanması amaçlanmıştır (Tran vd., 2020). Öte yandan sosyal hizmet uzmanları kriz durumlarında ihtiyaç duyulan psikososyal desteğin sağlanmasında Skype, Zoom, GotoMeeting gibi online platformlar aracılığıyla birey ve grup çalışmalarını gerçekleştirmektedirler (Dorn, 2020). Covid-19 salgınının ölümcül riski ve belirsizlik durumu nedeniyle bakım planlamalarının yapılmasında, yas ve kayıp sürecine yönelik müdahalelerin gerçekleştirilmesinde sosyal hizmet uzmanları önemli roller üstlenmektedirler (BASW, 2020). Özellikle yaşlı bireylerin hem bedensel hem de ruh sağlığı hizmetlerine olan ihtiyaçları online evde bakım ve takip mekanizmalarının uygulanmasını gerektirmektedir. Amerika'da Sağlık Hizmetlerini Geliştirme Enstitüsü'nün “The Conversation Project" adlı çalışması, yaşlı bireylerin aile üyelerinin de katılımıyla erken bakım planlamasının yapılmasını sağlamaktadır. Böyle bir çalışma, Covid-19 salgının yaşamsal süreçleri nasıl etkileyeceği ile ilgili danışmanlık da sunmaktadır (Dorn, 2020). Ülkemizde ise salgın sürecinde yaşlı bireylere yönelik telefon destek hatları kurularak psikososyal destek hizmetleri sunulmaya başlanmiştır.

Diğer yandan bazı ülkelerde Covid-19 salgınından etkilenen önemli gruplardan biri olarak kırsal alandaki yaşlılara yönelik psikososyal destek çalışmaları dijital ortamlarda gerçekleştirilmektedir. Örneğin Kanada'da kırsal alanda yaşaması nedeniyle Covid-19 salgınından olumsuz etkilenen bir grup olarak siyah ırktan yaşlı bireylere yönelik bütüncül, sanal ve kültürel temelli bir müdahale programı ile sosyal izolasyon ve yalnızlı̆ gerçekleştirilmektedir (Giwa vd., 2020). Böylece bu yaşlılara yönelik kültürel temelli müdahalelerle bu bireylerin yalnızlıklarını azaltabilecek yeni dijital bağlantılar kurmaları teşvik edilmektedir. Bu bağlantılarla yemek tarifi paylaşma, benzer yemekleri yaparak sanal ortamda paylaşma gibi aktiviteler etkileşimin arrtırılmasına katkı sağlamıştır. Sosyal hizmet uzmanları, dini inançları dikkate alarak pandemi hakkında endişe ve kaygılarını paylaşacak biçimde bu yaşlılar arasında diyaloğun geliştirilmesini teşvik etmektedirler. Ayrıca sosyal hizmet uzmanları bu yaşlılar arasında sanal iletişimi destekleyerek özbakımlarını gerçekleştirmelerine de katkıda bulunmaktadırlar. 
Salgın sürecinde karantina ve sosyal izolasyon uygulamaları sonucunda eğitim hizmetlerinin de online ortama taşınması, dijital altyapı ve donanım eksikliği nedeniyle var olan eşitsizlik durumunu daha da derinleştirmektedir. Buna yönelik olarak UNICEF, Microsoft ve Cambridge Üniversitesi iş birliğinde, eğitime devam edemeyen mülteci çocuk ve gençler için kurulan "Öğrenim Pasaportu (Learning Passport)" uygulaması, eğitimlerin dijital ortamda gerçekleştirilmesine olanak sağlamayı amaçlamaktadır (UNICEF, 2020). Ülkemizde ise ilkokul, ortaokul ve lise düzeyine kadar Eğitim Bilişim Ağı (EBA), dijital eğitim platformu olarak hizmet sağlamaktadır. Bu noktada özellikle belirtilmelidir ki ülkemizde okul sosyal hizmeti uygulamaları gerçekleştirilememektedir. Oysa Covid-19 salgınının çocuklar üzerindeki biyo-psiko-sosyal etkileri gözönünde bulundurulduğunda okul sosyal hizmet uzmanlarının başta çocukların yeni normale uyum sağlamalarında rol almaları önemlidir. Bununla birlikte sosyal hizmet uzmanları eğitimde dijitalleşme sürecinde, çocuk ve gençlerin online eğitime erişimlerini deseklemek için ve sanal ortamda maruz kalabilecekleri siber zorbalığa karşı teknoloji desteği ile okul sosyal hizmeti müdahalelerini gerçekleştirebilirler. $\mathrm{Bu}$ hizmetlerin yürütülmesinde dijital okuryazarlık ve yapabilirlik; teknoloji kullanım standartlarına ve etik ilkelere hassasiyeti ve dijital profesyonelliği gerektirmektedir (Mishna vd., 2012). Bu nedenle son y1llarda sosyal hizmet uygulamalarında teknolojinin kullanımına ilişkin etik standartların oluşturulması özellikle Covid-19 salgınıyla birlikte daha da önem kazanmıştır.

\section{Sosyal Hizmet Uygulamalarında Teknolojinin Kullanımına İlişkin Standartlar}

Sosyal hizmet uzmanlarının müracaatçılarına hizmet sunmak, iletişim kurmak, bilgi toplamak, öğrencileri ve uygulayıcıları eğitmek için teknolojiden daha fazla yararlandığı günümüz uygulamaları bazı etik zorlukları da beraberinde getirmiştir (Reamer, 2018). Öngen (2014)'in araştırması da sosyal hizmet uzmanlarının mesleki çalışmalarında teknoloji kullanım standartlarını da içerecek biçimde pek çok sorun yaşadıklarını göstermektedir. Ayrıca teknolojinin, sosyal hizmet eğitimine yönelik yeni standartların ortaya çıkmasına neden olduğu da belirtilmektedir (Reamer, 2019). Bu durum, sosyal hizmette yeni etik standartların geliştirilmesine yönelik çalışmaları gerekli kılmıştır. Nitekim sosyal hizmette uluslararası düzeydeki önemli meslek örgütleri (NASW vd., 2017) tarafından sosyal hizmet uzmanlarının, mesleki çalışmalarında ve uygulamalarında teknolojiyi dijital ortamda kullanabilmeleri için teknoloji kullanım standartları oluşturulmuştur (Tablo 1).

$\mathrm{Bu}$ standartların, sosyal hizmet uzmanlarının teknoloji kullanımına rehberlik etmesi ve teknolojiyi kullanırken etik sorumluluklarına dair farkındalıklarını artırması amaçlanmaktadır. Ayrıca sosyal hizmet uzmanlarını, işverenleri ve toplumu bu mesleki uygulama standartları hakkında bilgilendirmek de önemlidir. Bu standartlar "kamuya doğru bilgiyi sağlayabilme", "sosyal hizmetleri planlayabilme ve sunabilme", "sosyal hizmetlerle ilgili bilgiyi toplayabilme, yönetebilme ve kayıt altına alabilme", "sosyal hizmet eğitimi ve süpervizyon" olmak üzere dört temel başlık altında Tablo 1 'de belirtilmiştir (NASW vd., 2017). Kamuya doğru bilgiyi sağlayabilme standartları sosyal hizmet uzmanlarının kamuoyuna bilgi vermek için teknolojiyi kullanırken ya da savunuculuk yaparken mesleğin değerlerine bağlı kalması gerektiğini vurgulaması açısından önemlidir. Özellikle Covid-19 sürecinde doğru bilginin dijital ortamda paylaşılması ve yayılması açısından teknoloji kullanımında bu standarta meslek uzmanlarının bağlı kalması, başta halk sağlığı için önemli bir gerekliliktir. Salgın sürecinde danışmanlık, vaka yönetimi, destek ve diğer sosyal hizmet işlevleri dâhil olmak üzere teknolojinin, çeşitli amaçlarla sosyal hizmet uzmanları tarafindan kullanılabilmesi de gerekir. Ayrıca hizmetlerin elektronik yollarla alınmasından müracaatçının fayda sağlayıp sağlamayacağının değerlendirilmesinde ve alternatif hizmet yöntemlerinin sunulmasında sosyal hizmetleri planlayabilme ve sunabilme standartlarına dikkat etmek önemlidir.

Tablo 1: Sosyal Hizmet Uygulamaları İçin Teknoloji Kullanım Standartları

\begin{tabular}{l|cl}
\hline Kamuya Doğru Bilgiyi & $\bullet$ & Etik ve değerler \\
Sağlayabilme & $\bullet$ & Benliğin temsili ve bilginin doğruluğu \\
\hline
\end{tabular}




\begin{tabular}{|c|c|}
\hline $\begin{array}{l}\text { Sosyal Hizmetleri } \\
\text { Planlayabilme ve } \\
\text { Sunabilme }\end{array}$ & $\begin{array}{ll}\text { - } & \text { Sosyal hizmet uygulamaları için teknolojinin etik kullanımı } \\
\text { - } & \text { Lisans ya da diğer akreditasyon türleri gerektiren hizmetler } \\
\text { - } & \text { Sosyal hizmet uygulamalarının sunulmasını yöneten kanunlar } \\
\text { - } & \text { Bilgilendirilmiş onam: elektronik sosyal hizmet hizmetleri sunmanın yararları } \\
\text { - } & \text { ve risklerinin tartı̧ıllması } \\
\text { - } & \text { Yetkinlik: hizmet sağlamak için teknolojiyi kullanırken gerekli bilgi ve } \\
& \text { beceriler } \\
\text { - } & \text { Gizlilik ve teknoloji kullanımı } \\
\text { - } & \text { Elektronik ödemeler ve alacaklar } \\
\text { - } & \text { Mesleki sınırların korunması } \\
\text { - } & \text { Kişisel teknolojinin iş amaçlı kullanımı medya politikası } \\
\text { - } & \text { Elektronik sosyal hizmet kapsamındaki hizmetlerin plansız kesintileri } \\
\text { - } & \text { Acil durumlarda sorumluluk } \\
\text { - } & \text { Elektronik ve çevrimiçi görüşler } \\
\text { - } & \text { Organizasyon ve savunuculuk } \\
\text { - } & \text { Bağış } \\
\text { - } & \text { Müracaatçılara birincil bağlllık } \\
\text { - } & \text { Gizlilik } \\
\text { - } & \text { Bygun sinırlar } \\
\text { - } & \text { Teknorsiz ihtiyaçları karşıllama } \\
\text { - } & \text { Programa dayalı ihtiyaç değerlendirmeleri } \\
\text { - } & \text { Güncel bilgi ve yetkinlik } \\
\text { - } & \text { Yönajların kontrolü } \\
\text { - } & \text { Çevrimiçi araştırma yürütme } \\
\text { - } & \text { Sosyal medya politikaları } \\
\end{array}$ \\
\hline $\begin{array}{l}\text { Sosyal Hizmetlerle İlgili } \\
\text { Bilgiyi Toplayabilme, } \\
\text { Yönetebilme ve Kayıt } \\
\text { Altına Alabilme }\end{array}$ & 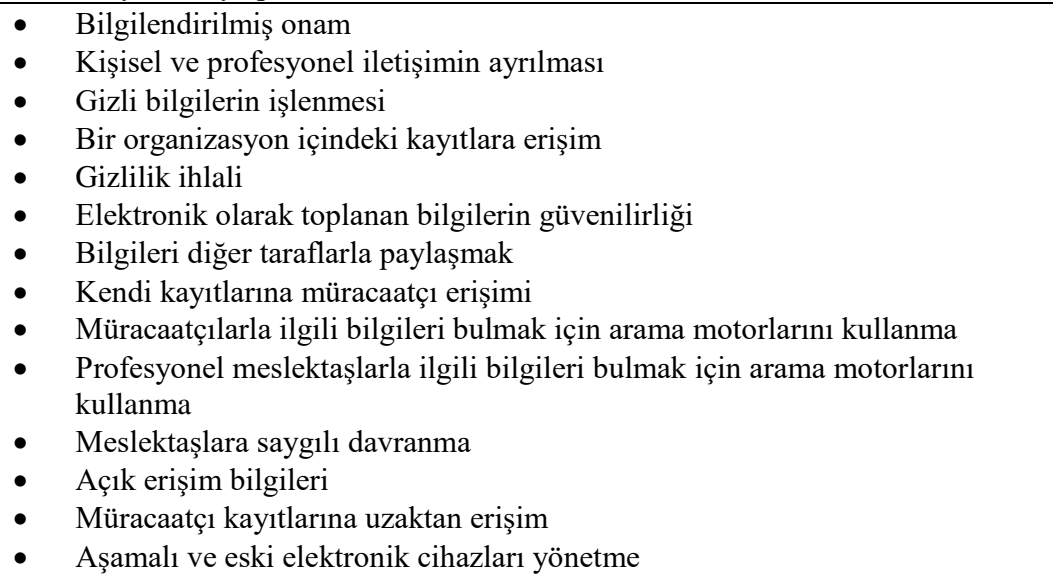 \\
\hline $\begin{array}{l}\text { Sosyal Hizmet Eğitimi } \\
\text { ve Süpervizyon }\end{array}$ & $\begin{array}{ll}\text { - } & \text { Sosyal hizmet eğitiminde teknolojinin kullanımı } \\
\text { - } & \text { Sosyal hizmet uzmanlarını teknolojinin uygulamada kullanımı konusunda } \\
\text { - } & \text { Sürekli eğitim } \\
\text { - } & \text { Sosyal medya politikaları } \\
\text { - } & \text { Değerlendirme } \\
\text { - } & \text { Teknolojik aksaklıklar } \\
\text { - } & \text { Uzaktan eğitim } \\
\text { - } & \text { Destek } \\
\text { - } & \text { Akademik standartların sürdürülmesi } \\
\text { - } & \text { Eğitimci-öğrenci sınırları } \\
\text { - } & \text { Alan talimatı } \\
\text { - } & \text { Sosyal hizmet süpervizyonu }\end{array}$ \\
\hline
\end{tabular}


(NASW, ASWB, CSWE ve CSWA, 2017)

Sosyal hizmetlerle ilgili bilgiyi toplayabilme, yönetebilme ve kayıt altına alabilme standartları ise sosyal hizmet uzmanlarının bilgi toplamak, yönetmek ve depolamak için teknolojiyi kullandıklarında uymaları gereken etik standartları öne çıkarır. Günümüzde sosyal hizmet uygulamalarında tüm bu süreçler büyük ölçüde dijital ortamda yapılmaktadır. Ancak Covid-19 salgınıla hizmetlerin artan oranda dijitalleştiği ve bunun sosyal hizmet uygulamlarına da yansıdığı görülmektedir. Bu durum dijital ortamda işlenmesi gereken daha fazla "veri"nin ortaya çıkmasına zemin hazırlamaktadır. Ayrıca Covid-19 salgını sürecinde özellikle toplumun hemen her kesiminden yaş grubunun bu salgından etkilendiği göz önünde bulundurulduğunda bu bireyler, gruplar, aileleri, topluluklar ve topluma yönelik mesleki müdahalelerde gizlilik, mahremiyet gibi hassasiyet gerektiren konularda meslek uzmanlarının bu standartları bilerek dikkatli ve özenli olabilmeleri gerekir.

Ayrıca teknolojik gelişmeler, sosyal hizmetin eğitim, öğretim ve süpervizyon süreçleri üzerinde de etkili olmakta, teknolojinin kullanımı bu alanda giderek gelişmekte ve yaygınlaşmaktadır. Aslında sosyal hizmet eğitimi, öğretimi ve süpervizyonu için teknolojinin nasıl kullanılacağına ilişkin tartışmaların (Ege ve Altındağ, 2018; Reamer, 2019; Tuncay, 2020) devam ettiği günümüzde Covid-19 salgını zorunlu olarak online eğitime geçişe neden olmuştur. $\mathrm{Bu}$ kapsamda sosyal hizmet eğitimi ve süpervizyonu ile ilişkili standartlar daha önemli hale gelmektedir. Çünkü bu standartlar eğitim ve süpervizyon sunumunda teknolojinin kullanımına ilişkin sosyal hizmet uzmanlarına rehberlik etmektedir. Nitekim üniversite öğrencileriyle yapılan bir araştırmada e-ders memnuniyeti ile öğretici yenilikçiliği arasında güçlü bir ilişki bulunmuştur (Atasoy, Özden ve Kara, 2020). Bu durum eğitim amacıyla teknoloji kullanımında teknolojik gelişmeleri takip etmenin ve kendini yenilemenin önemini göstermektedir.

Diğer yandan bu standartlar eğitim ve süpervizyon için teknolojinin etik kullanımını, akademik standartları ve eğitimci-öğrenci sınırlarını ön plana çıkarmaktadır (NASW vd., 2017). Bunun yanı sıra teknolojinin uygulamada kullanımı konusunda sosyal hizmet uzmanlarının eğitimini, sürekli eğitimi vurgulayarak bu alandaki yetkinliği arttırmanın önemine dikkat çekmektedir (NASW vd., 2017).

Newfoundland ve Labrador Sosyal Hizmet Birliği (NLASW, 2012) ise "dijital çağda" teknolojinin, sosyal hizmet uygulamasının ayrılmaz bir parçası haline geldiğini vurgulamaktadır. $\mathrm{Bu}$ doğrultuda mesleki uygulamalarda teknoloji kullanımı konusunda sosyal hizmet uzmanlarını desteklemek, teknolojiyi kullanırken uygulama hususları ve etik sorumluluklar konusunda farkındalığı artırmak ve hizmet sağlayıcıları ile yararlanıcıları uygulama standartları hakkında bilgilendirmek amaciyla 8 maddeden oluşan Tablo 2'deki standartlar oluşturulmuştur (NLASW, 2012). NLASW (2012) tarafından oluşturulan bu standartlarda teknoloji kullanımının, sosyal hizmet mesleğinin değerlerine, etik kurallarına ve ilkelerine dayanması gerektiği vurgulanmaktadır. Ayrıca teknolojinin yeterlilikler ve yetkinlikler dâhilinde kullanımının önemli olduğu, teknoloji kullanımına ilişkin müracaatçının bilgilendirilmiş onamının esas olduğu ve bu kullanımın kurum politikalarına, etik standartlara ve uygulama yönergelerine uygun olması gerektiği vurgulanmaktadır. Ayrıca mesleki müdahale sürecinde teknoloji kullanımının yetki alanı sınırlarını aşmaması gerektiği, bilgi toplamak ya da araştırma yapmak için teknoloji kullanımında etik güvenilirliğin sağlanması, çıkar çatışmaları, ikili ve çoklu ilişkiler ve sınırlarla ilgili konulara dikkat edilmesi gerektiği de belirtilmektedir.

\section{Sonuç ve Öneriler}

Covid-19 salgını öncesinde sosyal hizmetlerin planlanmasından yürütülmesine kadar pek çok aşamada dijital teknolojilerin kullanılması gerektiği vurgulanmıştır (Commission of the European Communities, 2006). Son yıllarda özellikle İngiltere gibi gelişmiş pek çok ülkede sağlık 
ve sosyal bakımı da içerecek biçimde devlet politikalarında "dijitalleşme" vurgusu ile dijital teknolojilerin kullanılabilmesi öncelikli hale gelmiştir (Maguire vd., 2018).

Tablo 2: NLASW (2012)'nin Sosyal Hizmet Uygulamalarında Teknoloji Kullanım Standartları

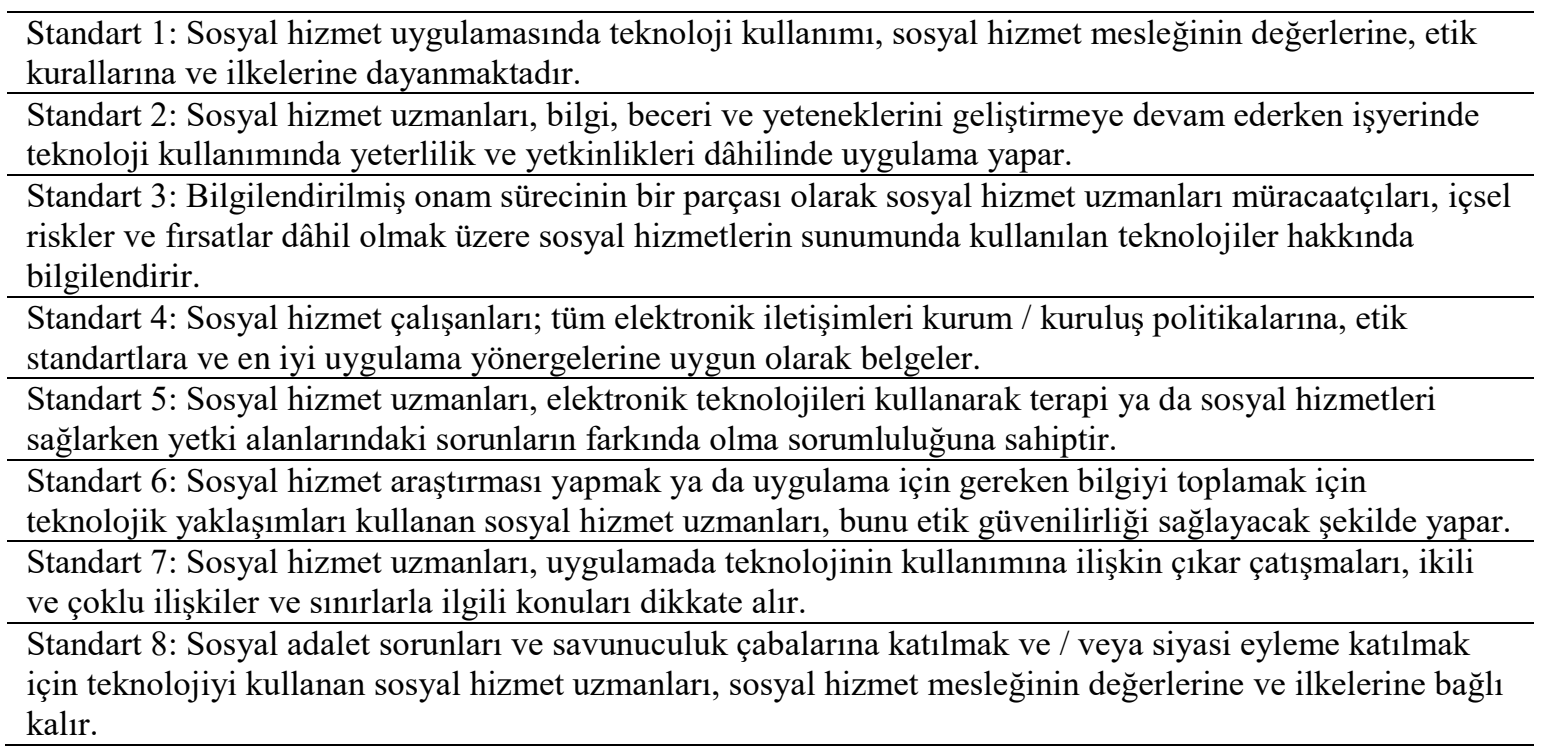

Covid-19 salgınıyla birlikte özellikle sağlık ve sosyal bakım alanlarında sosyal hizmetlerin sunumunda ve dolayısıyla refahın artırılmasında teknoloji desteği öne çıkmaktadır (Kennedy ve Yaldren, 2017). Ülkemizde de kamu yönetiminde dijital dönüşüm, e-devlet (elektronik devlet) ile başlamış ve kamu hizmetlerinin sunumunda bilgi ve iletişim teknolojileri öne çıkmıştır. Bu bağlamda kamu yönetim süreçlerinin dijitalleşmesi hem bir kamu politikası hem de ülkemizin kalkınma hedeflerine ulaşmada yeni bir yol haritası ve reform olduğu söylenebilir. Bu dönüşümde koordinatör devletin uygulayıcılarından biri olarak yeni reformu sürdürecek olan kurum ise Cumhurbaşkanlığı Dijital Dönüşüm Ofisi'dir (Tamer ve Övgün, 2020). Bir kamu hizmeti olarak sürdürülen sosyal hizmetlerin, özellikle kamu politikalarını doğrudan etkileyen Covid-19 salgını ve benzer küresel sağllk riski durumlarında, dijital ortamda sürdürülmesi için kamuda dijitalleşme dönüşümüne yönelik çalışmalar değerlidir. Ayrıca kamunun sosyal hizmetler sisteminde Covid-19 küresel sağlık krizinin hemen her ülkenin ekonomik açıdan daralmasına etkileri göz önüne alındığında kaynakların etkin ve yerinde kullanımı önem arz eder. Bu nedenle sosyal hizmet uzmanlarının kriz sürecinde kesintisiz bir biçimde bu hizmetleri dijital ortamda yürütülebilmeleri için gereksinim duydukları materyal ve insansal kaynaklara yatırımların gerekli olduğu düşünülmektedir.

Diğer yandan bu hizmetlerin sunumunda sosyal hizmet uzmanlarının, dijital teknolojileri müracaatçı odaklı kullanabilmeleri için bilgi, beceri ve değer temelinde dijital yapabilirliklerinin geliştirilmesi önemlidir. Çünkü sağlığın korunması gibi birincil öneme sahip Covid-19 salgını gibi durumlarda mesleki uygulamaların, yüz yüze yürütülmesinin mümkün ol(a)mayacağı deneyimlenmektedir. Böyle durumlarda müracaatçı gruplarına yönelik hizmetlerin kesintisiz olarak devam edebilmesinin, mevcut hizmetlerin hak temelli sunumu açısından önemli olduğu fark edilmiştir. Bunun yanı sıra kriz durumlarında dezavantajlı grupların sosyal hizmet gereksinimlerinin arttığı ve hatta yeni müracaatçı gruplarının ortaya çıktığı bilinmektedir. Bu durum, geleneksel yöntemlerin yerini alacak alternatif hizmet üretme yollarına gereksinimi artırmaktadır. Bu noktada dijital teknolojilerle yeni sosyal hizmet uygulama yöntemlerinin geliştirilmesine, bu teknolojiler aracılığıla mesleki uygulamaların desteklenmesine, bu uygulamalarda teknoloji kullanım standartlarının belirlenmesine ve yerleşik hale getirilmesine gereksinim vardır. Zira bu konuda yapılan çalışmalar sınırlı olmakla birlikte Öngen (2014)'in Covid-19 salgınından önce bir insani hizmet örgütünde yapmış olduğu araştırma, sosyal hizmetlerde teknoloji desteğinin çoğunlukla 
kuruluş yönetimi düzeyinde kullanıldığını göstermiştir. Ancak Covid-19 salgınıyla birlikte bu teknolojilerin kırılgan grupların ihtiyaçlarına cevap üretmek üzere sosyal politika oluşturma, doğrudan hizmet sunumu ve hizmet alanlar düzeyinde kullanımının desteklenmesi son derece önemlidir. Çünkü Covid-19 salgını ve böyle bir salgın riski durumunda desteğe ihtiyaç duyan müracaatçıların artması dikkate alındığında müracaatçıların ihtiyaçlarını ve sorunlarını mümkün olan en kısa sürede belirlemek sosyal hizmet uzmanlarının görevidir. Bu bağlamda sosyal hizmet uzmanlarının böyle durumlarda hızlı, etkin ve kesintisiz hizmet verebilmeleri için gereksinim duydukları dijital donanıma ilişkin eksiklikleri, hangi hizmetlerin hangi dezavantajlı gruplar için öncelikli olduğu ve ne tür hizmetlerin dijital ortamda gerçekleştirilebileceği gibi örgütsel düzeyde yapılacak araştırmalara da ihtiyaç vardır. Zira bu araştırmalar her insani hizmet örgütünün hedef grubunu oluşturan müracaatçıların ihtiyaç ve beklentilerinin Covid-19 salgını odağında belirlenerek teknoloji desteğinin ihtiyaçlara yönelik kulanılması açısından kanıt temeli oluşturmada etkili olabilir.

Diğer yandan sosyal hizmet uzmanlarının dijital yapabilirliklerine yönelik ihtiyaçlarının belirlenmesi de gerekmektedir. Böylece Covid-19 salgını sürecinde özel gereksinimli müracaatçılara ilişsin düzenli/sistemli kayıt ve rapor tutma, bu kayıt ve raporların daha işlevsel hale getirilmesi için idari işleyişi dijital ortamda nesnel ölçütlerle inceleyebilme, sosyal hizmet uzmanlarının birbirlerinin çalışmalarını dijital ortamda daha sistemli bir biçimde takip edebilmeleri, çalışan üzerindeki iş yükünün takibini kolaylaştırma gibi olanakların geliştirilmesi de mümkün olabilir.

Ayrıca sosyal hizmetlerin sunumunda dijital dönüşüm için meslek uzmanlarının ihtiyacı doğrultusunda bilgi, beceri ve değer temelini güçlendirmek için onlara yönelik bilgilendirici ve bilinç artırıcı eğitim çalışmalarına gereksinim olabilir. Bu noktada sosyal hizmet akademisyenlerinden destek alınması ve kanıt temelli bilgi sağlanması değerlidir. Bunun yanı sıra sosyal hizmet akademisyenlerinin dijital teknolojiler aracılığıyla Covid-19 salgını gibi kriz durumlarında etkin olarak kullanılabilecek yeni yöntemler ve alternatif mesleki uygulamalar üzerine çalışmalarının yararlı olacağı düşünülmektedir.

Diğer yandan günümüzde sosyal hizmet uygulayıcılarının; özellikle kriz durumlarında teknolojiyi kullanabilme yetkinliğinin önemli olduğu uluslararası literatürdeki iyi uygulama örnekleri üzerinden fark edilmektedir. Bu nedenle sosyal hizmet lisans, yüksek lisans ve doktora eğitimi veren programların, geleceğin sosyal hizmet uzmanlarına dijital yetkinlik kazandırmaya yönelik yeterliliklerini sorgulamaları ve bu konuda teorik/uygulamaya dayalı dersleri müfredata eklemeleri gerekir.

Teknolojinin sosyal hizmet uygulamalarında da önem kazandığı Covid-19 salgını sürecinde teknoloji kullanım standartlarına farkındalık kazandırmak önemlidir. Çünkü teknoloji kullanım standartlarına bağlı kalarak sosyal hizmetlerin sunumunu sağlamak, hem müracaatçıların hem meslek uzmanlarının hem de toplumun sağlığını korumak ve iyileştirmek için gereklidir. Ancak ülkemizde sosyal hizmet uygulamalarında teknoloji kullanım standartları henüz belirlenmiş değildir. $\mathrm{Bu}$ standartlar müracaatçının yararının korunması ve sosyal hizmetlerde teknoloji kullanımı ile birlikte etik ihlallerin ortaya çıkmaması açısından son derece önemlidir.

\section{Kaynakça}

Akın, L., \& Gözel, M. G. (2020). Understanding dynamics of pandemics. Turkish Journal of Medical Sciences, 50(4), 515-519. https://dx.doi.org/10.3906/sag-2004-133

Arslan Tomas, S., \& Şavur, E. (2018). Afet ve acil durumlarda psikososyal destek hizmetleri saha çalışanları için el kitabı. UNICEF Türkiye Temsilciliği.

Atasoy, R., Özden, C. \& Kara, D. N. (2020). Covid-19 pandemi sürecinde yapılan E-ders uygulamalarının etkililiğinin öğrencilerin perspektifinden değerlendirilmesi. Turkish Studies, 15(6), 95-122. https://dx.doi.org/10.7827/TurkishStudies.44491 
Attepe-Özden, S., Pak, M. D., \& İçağasığlu-Çoban, A. (2017). Sosyal hizmette iyilik hali kavramı. Türkiye Sosyal Hizmet Araştırmalart Dergisi, 1(2), 87-104. https://dergipark.org.tr/tr/pub/tushad/issue/31868/360203

BASW. (2020). End of life social work during Covid-19. https://www.basw.co.uk/end-life-socialwork-during-covid-19

BASW \& SCIE. (2019). Digital capabilities for social workers: Stakeholders' report. https://www.scie.org.uk/files/social-work/digital/digital-capabilities-download.pdf

Birinci, M. (2018). Sosyal hizmet örgütleri ve yenilikçi yaklaşımların önemi üzerine bir değerlendirme. Sosyal Çalı̧̧ma Dergisi, 2(2), 43-62. https://dergipark.org.tr/en/download/article-file/601941

Brooks, S. K., Webster, R. K., Smith, L. E., Woodland, L., Wessely, S., Greenberg, N., \& Rubin, G. J. (2020). The psychological impact of quarantine and how to reduce it: Rapid review of the evidence. The Lancet, 395(10227), 912-920. https://doi.org/10.1016/S0140-6736(20)304608

Buz, S. (2002). Afet yönetimi ve sosyal hizmet. G. Erkan, F. Demiröz \& S.Ö. Çetin (Editörler). Sosyal hizmet sempozyumu 2001: Deprem ve sosyal hizmetler. (1.bask1, s. 56-67). Aydınlar Matbaacilık.

CASW. (2008). What is social work?. https://www.casw-acts.ca/en/what-socialwork\#: :text=Social\%20work\%20is\%20a\%20profession,the $\% 20$ community $\% 20$ to $\% 20$ resolve\%20problems

Csiernik, R., Furze, P., Dromgole, L. \& Rishchynski, G. M. (2006). Information technology and social work - the dark side or light side?. Journal of Evidence-Based Social Work, 3(3-4), 925. https://doi.org/10.1300/J394v03n03_02

Commission of the European Communities. (2006). Green paper: A European strategy for sustainable, competitive and secure energy. https://europa.eu/documents/comm/green_papers/pdf/com2006_105_en.pdf

Deloitte. (2020). Yeni nesil teknolojilerin Covid-19 mücadelesindeki önemi ülke örnekleri. https://www2.deloitte.com/tr/tr/pages/consulting/articles/yeni-nesilteknolojilerin-covid-19-mucadelesindeki-onemi.html

Dorn, C., (2020). COVID-19 advance care planning in health care practice. https://www.socialworkers.org/LinkClick.aspx?fileticket=nE5MuNSwnZE\%3d\&portalid= 0

Dunn, S., Braddell, A. \& Sunderland, J. (2014). Digital capabilities in social care: Final report. Skills For Care. http://www.saradunnassociates.net/fileadmin/saradunn/downloads/clients/Skills_for_Care/Digital-CapabilitiesResearch-Report-300714-FINAL.pdf

Duyan, V. (2002). Doğal afetler ve sosyal hizmet. G. Erkan, F. Demiröz \& S.Ö. Çetin (Eds). Sosyal hizmet sempozyumu 2001: Deprem ve sosyal hizmetler. (1. baskı, s. 35-41). Aydınlar Matbaacilık.

Ege, A. \& Altındağ, Ö. (2018). Sosyal hizmet akademisyenlerinin teknoloji kullanımlarının incelenmesi. Ufkun Ötesi Bilim Dergisi, 18(1), https://dergipark.org.tr/tr/download/article-file/626191 
Evans, L. (2008). Professionalism, professionality and the development of education professionals. British Journal of Educational Studies, 56(1), 20-38. https://doi.org/10.1111/j.14678527.2007.00392.x

Gilster, P. (1997). Digital literacy. John Wiley.

Giwa, S., Mullings, D. V., \& Karki, K. K. (2020). Virtual social work care with older black adults: A culturally relevant technology-based intervention to reduce social isolation and loneliness in a time of pandemic. Journal of Gerontological Social Work, 13. https://doi.org/10.1080/01634372.2020.1800885

Hanley, T. (2009). The working alliance in online therapy with young people: Preliminary findings. British Journal of Guidance \& Counselling. 37(3), 257269.https://doi.org/10.1080/03069880902956991

HEE. (2016). Digital literacy: Towards a definition. The NHS Constution. https://www.hee.nhs.uk/sites/default/files/documents/1.\%20Digital\%20literacy\%20Toward s\%20 a\%20definition.pdf

IASC. (2020). Covid-19: How to include marginalized and vulnerable people in risk communication and community engagement. https://interagencystandingcommittee.org/covid-19-howinclude-marginalized-and-vulnerable-people-risk-communication-and-communityengagement

IFSW. (2000). International definiton of social work. http://www.ifsw.org/f38000138.html

ILO. (2020). Uluslararası Çalışma Örgütü (ILO) bilgi notu COVID-19 ve çalışma yaşamı: Etkiler ve yanitlar (18 Mart 2020). https://www.ilo.org/wcmsp5/groups/public/---europe/---rogeneva/---ilo ankara/documents/briefingnote/wcms_740193.pdf

Kennedy, S. \& Yaldren, J. (2017). A look at digital literacy in health and social care. British Journal of Cardiac Nursing, 12(9), 428-432. https://doi.org/10.12968/bjca.2017.12.9.428

La Placa, V., McNaught, A., \& Knight, A. (2013). Discourse on wellbeing in research and practice. International Journal of Wellbeing, 3(1), 116-125. doi: 10.5502/ijw.v3i1.7

Maguire, D., Evans, H., Honeyman, M., \& Omojomolo, D. (2018). Digital change in health and social care. The King's Fund. https://www.kingsfund.org.uk/sites/default/files/201806/Summary_digital_change_health_care_Kings_Fund_June_2018.pdf

Midkiff, D. M. \& Joseph-Wyatt, W. (2008). Ethical issues in the provision of online mental health services (etherapy). Journal of Technology in Human Services, 26(2/4), 310-332. https://doi.org/10.1080/15228830802096994

Mishna, F., Bogo, M., Root, J. Sawyer, J.-L. \& Khoury-Kassabri, M. (2012). "It Just Crept In”: The digital age and implications for social work practice. Clinical Social Work Journal, 40(3), 277-286. https://doi/10.1007/s10615-012-0383-4

NASW, ASWB, CSWE \& CSWA. (2017). Standards for technology in social work practice. https://www.socialworkers.org/includes/newIncludes/homepage/PRA-BRO

33617.TechStandards_FINAL_POSTING.pdf

NHS. (2018). A health and care digital capabilities framework. https://www.hee.nhs.uk/sites/default/files/documents/Digital\%20Literacy\%20Capability\% 20Framework\%202018.pdf 
NLASW. (2012). Standards for technology use in social work practice. https://nlasw.ca/sites/default/files/inline-

files/Standards_For_Technology_Use_In_Social_Work_Practice.pdf

Öngen, Ç. (2014). Aile ve Sosyal Politikalar Bakanlı̆̆ı'na bağlı sosyal hizmet kuruluşlarının sosyal hizmet uygulamalarında bilişsim teknolojilerinin kullanımı: Ankara ili örneği (Yüksek Lisans Tezi). Hacettepe Üniversitesi

Reamer, F. G. (2018). Ethical standards for social workers' use of technology: Emerging consensus. Journal of Social Work Values and Ethics, 15(2), 71-80. https://jswve.org/download/15-2/articles15-2/71-Use-of-technology-JSWVE-15-2-2018Fall.pdf

Reamer, F. G. (2019). Social work education in a digital world: Technology standards for education and practice. Journal of Social Work Education, 55(3), 420-432. https://doi.org/10.1080/10437797.2019.1567412

Smith, A. C., Thomas, E., Snoswell, C. L., Haydon, H., Mehrotra, A., Clemensen, J., \& Caffery, L. J. (2020). Telehealth for global emergencies: Implications for coronavirus disease 2019 (COVID-19). Journal of Telemedicine and Telecare, 26(5), 309-313. https://doi.org/10.1177/1357633X20916567

Tamer, H.Y. \& Övgün, B. (2020). Yapay zeka bağlamında dijital dönüşüm ofisi. Ankara Üniversitesi SBF Dergisi, 75(2), 775-803. https://dergipark.org.tr/tr/download/article-file/974381

Taylor, A. M. (2019). Examining the contribution of social work education to the digital professionalism of students for practice in the connected age (Doctoral Dissertation). University of Central Lancashire.

Taylor, A. (2017). Social work and digitalization: Bridging the knowledge gaps. Social Work Education, 36(8), 869-879. https://doi.org/10.1080/02615479.2017.1361924

Tran, B. X., Hoang, M. T., Vo, L. H., Le, H. T., Nguyen, T. H., Vu, G. T., ... \& Ho, R. C. (2020). Telemedicine in the COVID-19 pandemic: Motivations for integrated, interconnected, and community-based health delivery in resource-scarce settings? Frontiers in Psychiatry, 11, 13. https://dx.doi.org/10.3389\%2Ffpsyt.2020.564452

Tuncay, T. (2004). Afetlerde sosyal hizmet: 1999 yll Marmara ve Bolu Düzce depremleri sonrasında gerçekleştirilen sosyal hizmet uygulamaları. Özbay Ofset Matbaacılık.

Tuncay, T. (2005). İnsani hizmet örgütlerinin yönetiminde bilişim sistemleri. Toplum ve Sosyal Hizmet, 16(1), 125-146.

https://www.academia.edu/10076604/\%C4\%B0nsani_Hizmet_\%C3\%96rg\%C3\%BCtlerini n_Y\%C3\%B6netiminde_Bili\%C5\%9Fim_Sistemleri

Tuncay, T. (2010). E-sosyal hizmetler: İnsani hizmetlerde bilişim teknolojisi uygulamaları. İzmir 3. İleri Yaş Sempozyumu: "Kırılgan Yaşlı”. (1.bask1, s. 57-67). Ege Geriatri Derneği.

Tuncay, T. (2020). Çevrimiçi sosyal hizmet eğitimi: Fursatlar ve engeller. Türkiye Sosyal Hizmet Araştırmaları Dergisi, 4(1), 18-25. https://dergipark.org.tr/tr/download/articlefile/1133355

TÜBA. (2020). Covid-19 pandemi değerlendirme raporu. Türkiye Bilimler Akademisi Yayınları. http://www.tuba.gov.tr/files/images/2020/kovidraporu/T\%C3\%9CBA\%20Covid19\%20Raporu\%201.\%20G\%C3\%BCncelleme.pdf

UN. (2020a). Commodity exporters face mounting economic challenges as pandemic spreads, urgent, preemptive measures needed to address twin economic and health crisis. 
https://www.un.org/development/desa/dpad/wpcontent/uploads/sites/45/publication/PB_60. pdf

UN. (2020b). "Yeni normal: BM Covid-19 sonrası dönemde ekonomilerin toparlanmast ve istihdamın korunması için yol haritasını açıkladı". https://turkey.un.org/tr/43294-yeninormal-bm-covid-19-sonrasi-donemde-ekonomilerin-toparlanmasi-ve-istihdaminkorunmasi

UNDP. 21. (2019). yüzyllda insani gelişmedeki eşitsizlikler. https://www.undp.org/content/dam/turkey/hdr2019/UNDP-TR-EN-HDR2019-OVERVIEW-TUR-TR.pdf

UNICEF. (2020) "UNICEF ve Microsoft, COVID-19 salgınının yol açtı̆̆ı eğitim krizine müdahale etmek için büresel eğitim platformu kuruyor". https://www.unicef.org/turkey/bas\%C4\%B1n-b\%C3\%BCltenleri/unicef-vemicrosoft-covid-19-salg\%C4\%B1n\%C4\%B1n\%C4\%B1n-yola\%C3\%A7t\%C4\%B1\%C4\%9F\%C4\%B1-e\%C4\%9Fitim-krizine-m\%C3\%BCdahale-etmek

UNFPA. (2020). Toplumsal cinsiyet perspektifinden Covid-19 cinsel sağlık, üreme sağllğının ve haklarının korunması ve toplumsal cinsiyet eşitliğinin teşvik edilmesi. Mart 2020. https://www.unfpa.org/sites/default/files/resource-pdf/Turkish_-COVID19_A_Gender_Lens_Guidance_Note.pdf

WHO. (2020a). Coronavirus disease 2019 (COVID-19) situation report - 72. https://www.who.int/docs/default-source/coronaviruse/situation-reports/20200401-sitrep72-covid-19.pdf?sfvrsn=3dd8971b_2

WHO. (2020b). Considerations in adjusting public health and social measures in the context of COVID-19 interim guidance. https://apps.who.int/iris/bitstream/handle/10665/331773/WHO-2019-nCoVAdjusting_PH_measures-2020.1-eng.pdf

WHO. (2020c). Getting your workplace ready for COVID-19: How COVID-19 spreads, 19 March 2020. https://apps.who.int/iris/handle/10665/331584

Yıldız, İ., Çıkrıç̧1lı, U. \& Yüksel, Ş. (2020). Karantinanın ruhsal etkileri ve koruyucu önlemler. https://www.psikiyatri.org.tr/TPDData/Uploads/files/KarantinaCOVID.pdf 